\title{
The level of socioeconomic development of EU countries and the state of ISO 14001 certification
}

\author{
Barbara Fura $^{1}$ Q Qingfang Wang ${ }^{2}$
}

Published online: 21 December 2015

(C) The Author(s) 2015. This article is published with open access at Springerlink.com

\begin{abstract}
This study examines the relationship between the level of socioeconomic development of the EU 28 countries and the adoption of International Organization for Standardization (ISO) 14001 environmental management system. First, through a multivariate comparative analysis of the secondary data obtained from the public statistics, a Hellwig's synthetic indicator is created to rank the level of socioeconomic development of the EU 28 countries. Then, using the total number of certificates issued in 2012 and the increase from 2011, this study has found a correlation between the level of national socioeconomic development and the adoption of ISO 14001 system in their businesses. Although there was no relationship between the number of ISO 14001 certificates in 2012 and the level of socioeconomic development at the national level, a weak negative correlation was observed between the increase of certification from 2011 to 2012 and the level of national socioeconomic development. The results suggest a higher interest in ISO 14001 adoption by the firms from the less developed countries than those from the more developed states.
\end{abstract}

Keywords Environmental management · ISO 14001 standard · Socioeconomic development · Hellwig's synthetic indicator · European Union

\section{Introduction}

The changing business environment and intensified competition have urged many companies to operate their businesses in compliance with accepted norms and standards which include not only general regulations of business activities, but also social norms and

Barbara Fura

bfura@ur.edu.pl

Qingfang Wang

Qingfang.Wang@ucr.edu

1 Faculty of Economics, University of Rzeszów, Ćwiklińskiej 2, 35-601 Rzeszów, Poland

2 School of Public Policy, University of California Riverside, Riverside, CA 92521, USA 
standards in the area of environmental protection (Chen and Chang 2013; Hąbek and Wolniak 2015). Commonly binding principles, norms and standards can bring greater predictability and thus reduced risks for businesses. It is specifically important for countries as members of international economic institutions and organizations, including countries newly admitted into the EU as well as those looking forward to accession. Yet, requirements for standardisation are relatively new issues that pose more challenges for companies from the less developed states.

Since the mid-1990s, various voluntary actions in environmental management have been adopted by firms around the world. One of the most notable practice is the adoption of International Organization for Standardization (ISO) 14001 standard (He et al. 2015; Hąbek 2014) developed by ISO, a non-governmental body located in Geneva, Switzerland. The ISO 14000 series of standards was based on the need expressed at the United Nations Conference on Environment and Development in Rio de Janeiro in 1992. The main aim of the new series of standards was to encourage businesses to systematically improve environmental quality (Bansal and Bogner 2002).

ISO 14001 is the only standard designed for the purpose of audit and certification in the ISO 14000 series. The core elements of the ISO 14001 standard include environmental policy, planning, implementation and operation, checking and corrective action, review, and improvement (Franchetti 2011). The ISO 14001 system supposes to be a worldwide solution, applicable in any organization who is interested in managing its environmental impacts for continuous improvements. The strength of this international standard lies in its flexibility to maintain the internal structures and prevailing features of the businesses while executing the most effective means to improve environmental impacts (Testa et al. 2014). Overall, the compliance of environmental management systems with ISO 14001 enables firms to identify and control their environmental impacts, improve their environmental performance continually, and implement a systematic approach to achieve environmental goals (McGuire 2014).

This is why the adoption of ISO 14001 can bring numerous internal and external benefits (e.g., Fura 2013; He et al. 2015; Nishitani 2010; Testa et al. 2014; To and Lee 2014; Zobel 2013), such as cost reduction, energy saving, improvement in environmental performance, process and product innovations, efficiency improvement, corporate image improvement, entering new markets, increase in market share, and reduction in insurance fees. Turk (2009) listed four aspects of benefits for ISO 14001 certified businesses: environmental benefits and internal operation, corporate management, marketing effects, and subcontractor relations. Similarly, Gavronski et al. (2008) argued that businesses will gain in productivity, financial, societal and market benefits.

Businesses in different countries, regions and industries are widely interested in the adoption of ISO 14001 (Qi et al. 2011). Although ISO 14001 compliance is not legally enforced, the total number of ISO 14001 adoptions in the world has steadily increased since the release of the system in 1996 (Lagodimos et al. 2007), reaching 301,647 certifications by 2013 (The ISO Survey 2013). $39.3 \%$ of the issued certificates in 2012 were for organizations located in European countries and the share of Europe remained the same in $2013(39.5 \%)$. In 2012 the worldwide increase in the total number of ISO 14001 certificates was $9 \%$, and the annual growth rate decreased to $6 \%$ in 2013. The increase in Europe was $11 \%$ in 2012, and the rate decreased to $6 \%$ in 2013 as well (The ISO Survey 2012, 2013).

Despite the positive effect of ISO 14001 adoption, the range and the scale of its benefits might differ among the businesses, depending on the business characteristics as well as their environments. At the global level, some studies have analyzed the effects of various 
economic, market, and regulatory factors on the adoption of ISO 14001 certification. For example, Neumayer and Perkins (2004) found that the number of ISO 14001 certificate is positively correlated with the income of the country, foreign direct investments, and exportation. In the same vein, Fikru (2014) showed that businesses that export, have some foreign ownership and are internationally connected have a higher probability of certifying.

Scholars around the world have examined the types of businesses adopting the ISO 14001 environmental management system. For example, Chapple et al. (2001) showed that among large manufacturing companies in the UK, the adoption of ISO 14001 system is related to the companies' market position. According to them, when their market position is stronger, the pressure to adopt the ISO 14001 becomes lower for these businesses. Other studies in Japan showed that companies are more willing to implement such systems if their activities are based on less complex processes, which suggests that businesses involved in high-risk activities are more likely to implement such systems (Takahashi and Nakamura 2010). To and Lee (2014) examined the dependency between the number of ISO 14001 certificate and export volume in the top 30 countries. They found that the relationship between the two factors weakens when the number of ISO 14001 certificate saturates. At the same time, some researchers argue that there is no connection between the adoption of ISO 14001 standard and the type of business or business location (e.g., Marimon et al. 2011).

Despite accumulation of the literature on the relationship between ISO 14001 adoption and business characteristics, knowledge is still very limited about the adoption of ISO 14001 systems and the external factors of business activity, such as the level of national development in the countries where the businesses are located. Therefore, the objective of the current study is to examine the relationship between the level of socioeconomic development of the EU member states and their adoption of ISO 14001 standard. Based on the above discussion of existing studies, we hypothesize that:

H Organizations located in less developed countries of EU are more likely to adopt ISO 14001 system than firms from more developed countries.

\section{Methodology}

\subsection{Data source}

The empirical analysis in this study was based on currently available statistical sources, i.e., Eurostat, EU economics-economic indicators platform, Central Statistical Office of Poland publications. Data on the ISO 14001 certification in the EU 28 member states were obtained from the official publications of ISO (The ISO Survey of Certifications 2012, 2013).

\subsection{Analysis}

Measuring socioeconomic development is highly complex due to the wide spectrum of covered factors (Grzebyk and Stec 2015). Thus, to examine the EU countries' development level we apply a multivariate comparative analysis, i.e., linear ordering of objects. Originally this method was created by Hellwig (1968) which allows to create a ranking of objects measured by multiple variables. Through this method, objects in study are ordered on the basis of their distance from the established reference object. 
We first select diagnostic variables to create a Hellwig's synthetic indicator, based on these variables' significance, the level of variability, and the level of correlation of variable pairs. The statistically formal criteria of the applied method concerns an appropriate level of variation of the features and a low correlation between the variables (Guyon and Elisseeff 2003). To examine the level of variation we apply the classical coefficient as provided below:

$$
v_{j}=\frac{S_{x_{j}}}{\bar{x}_{j}} \cdot 100,
$$

where $v_{j}$ is the coefficient of variation, $S_{x_{j}}$ is the standard deviation of the $j$ th variable, and $\bar{x}_{j}$ is the mean value of $j$ th variable. We take $10 \%$ critical value for the coefficient of variation (Perło 2014). This means that variables with the coefficient of variation less than or equal to 0.1 are considered as quasi-stable (i.e., devoid of enough information load) and thus are eliminated from the further analysis.

To measure the correlation between the variables we use Pearson's correlation coefficient given by (2):

$$
r_{x y}=r_{y x}=\frac{\frac{1}{n} \sum_{i=1}^{n}\left(x_{i}-\bar{x}\right)\left(y_{i}-\bar{y}\right)}{S_{x} S_{y}}=\frac{\operatorname{cov}(\mathrm{x}, \mathrm{y})}{S_{x} S_{y}},
$$

where $r_{x y}$ is the coefficient of correlation, $S_{x}$ and $S_{y}$ are standard deviations of the $x$ th and $y$ th variables, and $n$ is the number of variables. The critical value of the correlation coefficient is the absolute value of \pm 0.7 (Stec et al. 2014). Based on this criterion, we selected the variables for analyses whose coefficient of correlation with other variables is lower than this threshold value.

Different characteristics of each country have different units. To eliminate the problems with different units, we standardize their values through the following calculation (Gostowski 1970):

$$
z_{i j}=\frac{x_{i j}-\bar{x}_{j}}{S_{x_{j}}},
$$

where $i$ is the number of objects (countries), $j$ is the number of variables, $\bar{x}_{j}$ is the mean value of $j$ th variable, $S_{x_{j}}$ is the standard deviation of the $j$ th variable, and $z_{i j}$ is the standardized value of the $j$ th variable for the $i$ th object. We use these standardized values to establish the pattern of development, i.e., the "ideal object" with the coordinates: $z_{01}$, $z_{02}, \ldots, z_{0 k}$, where $z_{0 j}=\max _{i}\left\{z_{i j}\right\}$ represents variables that are stimulants; and $z_{0 j}=$ $\min _{i}\left\{z_{i j}\right\}$ represents variables that are destimulants. ${ }^{1}$

Then, for each object we calculate its distance from the "ideal object" by the following formula (Lesot 2006):

$$
d_{i}=1-\frac{D_{i 0}}{D_{0}}, \quad(i=1, \ldots, n),
$$

where $d_{i}$ is the measure of development proposed by Hellwig, $D_{i 0}$ is the Euclidean distance between the country and the "ideal object", and $D_{0}$ is the critical distance between the objects and the "ideal object". The calculation of the Euclidean distance $\left(D_{i 0}\right)$ is based on the following formulas:

\footnotetext{
1 Stimulant is a variable whose high value signals a favourable situation of an object. Destimulant is a variable whose high value signals an unfavourable situation of an object (Pociecha and Zając 1989).
} 


$$
\begin{gathered}
D_{i 0}=\sqrt{\sum_{j=1}^{m}\left(z_{i j}-z_{0 j}\right)^{2},} \\
D_{0}=\overline{D_{0}}+2 S_{0}, \\
\overline{D_{0}}=\frac{1}{n} \sum_{i=1}^{n} D_{i 0}, \\
S_{0}=\sqrt{\frac{1}{n} \sum_{j=1}^{m}\left(D_{i 0}-\overline{D_{0}}\right)^{2}} .
\end{gathered}
$$

The synthetic indicator calculated for each object (an EU country) is assumed to take a positive value that ranges from 0 to 1 (Ostasiewicz 1998). The closer the value of a given object is to the "ideal object", the higher the level of development.

Moreover, to simplify a comparison among countries' development level we apply a modification of the indicator according to the following formula (Sarama 2013):

$$
d_{i}^{\prime}=100 \cdot \frac{d_{i}}{\max \{d\}},
$$

where $\max \{d\}$ is the maximum value of the synthetic variable. Thus, the transformed indicator $\left(d^{\prime}\right)$ for the most developed country takes a value of 100 .

We also use the value of the indicator $\left(d^{\prime}\right)$ to create groups of objects with similar levels of socioeconomic development. In order to establish the class limits, we apply the arithmetic mean of the indicator $\left(\overline{d^{\prime}}\right)$ and the value of a standard deviation $(s)$, thus providing the following classification:

Group I contains countries with a high level of development: $d_{i}^{\prime}>\overline{d^{\prime}}+s$;

Group II contains countries with a level of development above average: $\overline{d^{\prime}}<d_{i}^{\prime} \leq \overline{d^{\prime}}+s$;

Group III contains countries with a level of development below average: $\overline{d^{\prime}}-s<d_{i}^{\prime} \leq \overline{d^{\prime}}$;

Group IV contains countries with a lowest level of development: $d_{i}^{\prime} \leq \overline{d^{\prime}}-s$.

To examine the relationship between the development level of the EU countries and ISO 14001 certification, we employ Pearson's correlation coefficient given by (2). The level of development of the countries is characterized by abovementioned Hellwig indicator. The absolute numbers of ISO 14001 certificate in the countries are difficult to compare with each other since they do not reflect the countries' characteristics (Casadesús et al. 2008). Thus, we introduce the relative measure of ISO 14001 certification through dividing the ISO 14001 certificate number in 2012 and its increase from 2011 to 2012 by countries' total population in 2012. Although both variables are in relative forms, it is still possible to use Pearson's correlation analysis to measure the relationship between the ISO adoption and national socioeconomic development. 


\subsection{Variables}

Socioeconomic development in a country is a multi-dimensional process influenced by many factors. Measuring the level of development thus requires choosing appropriate descriptive variables. This study used a set of 15 variables of national socioeconomic development to cover the areas of economy, environment and society (Borys 2010; Išljamović et al. 2015). Specifically, we employed the following indicators:

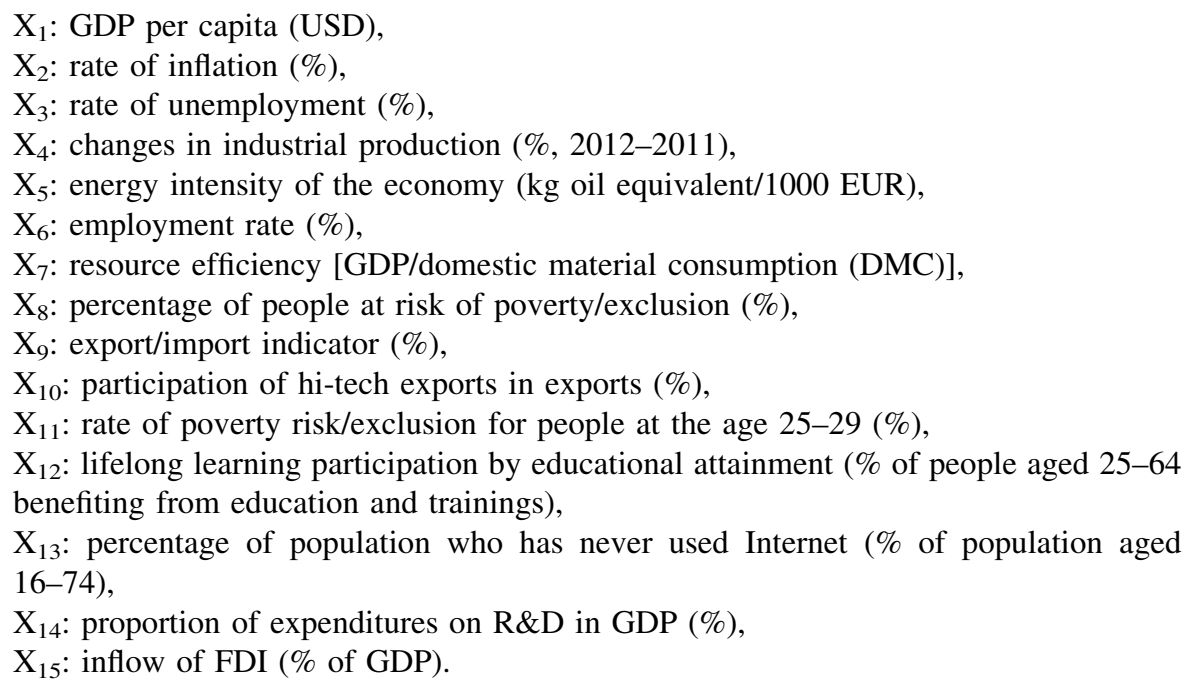

To measure the national economic development, we use traditional indicators such as GDP per capita, rate of inflation, rate of unemployment (employment) or export/import indicator. The first indicator $\left(\mathrm{X}_{1}\right)$ is to compare the standard of living in the countries. We examine the stability of the economies as well as their market security with the use of rate of inflation $\left(\mathrm{X}_{2}\right) . \mathrm{X}_{3}$ and $\mathrm{X}_{6}$ reflect the labor market situation and the changes in industrial production $\left(\mathrm{X}_{4}\right)$ indicates the economic activity in the member states. The position of the countries on the international trade is reflected by the export-import ratio $\left(\mathrm{X}_{9}\right)$. The share of hi-tech exports $\left(\mathrm{X}_{10}\right)$ represents the level of the technological advancement. The proportion of expenditures on $\mathrm{R} \& \mathrm{D}$ in GDP $\left(\mathrm{X}_{14}\right)$ examines the innovativeness of the countries. Essential for its improvement especially in less developed countries might be also the inflow of foreign direct investment reflected by $\mathrm{X}_{15}$.

In the area of environmental aspects of national development, we consider the energy intensity of the economy $\left(\mathrm{X}_{5}\right)$ and resource efficiency $\left(\mathrm{X}_{7}\right)$. The first indicator measures the energy consumption and its overall energy efficiency. The second one reflects the productivity of raw materials such as fuels, minerals, metals, as well as food, soil, water, air, biomass, and ecosystems.

The rest of the indicators deal with social issues of the development. The first area of interest is the problem of poverty reflected by poverty risk examined in general $\left(\mathrm{X}_{8}\right)$ and among the youth $\left(\mathrm{X}_{11}\right)$. The second issue is the education level of society expressed by the interest in lifelong education among the $25-64$ age group $\left(\mathrm{X}_{12}\right)$. The third one is the level of Internet usage as measured by the share of non-users among the 16-74 age group $\left(\mathrm{X}_{13}\right)$. We also treat this indicator as the proxy of standard of living.

The descriptive statistics for $\mathrm{X}_{1}-\mathrm{X}_{15}$ variables are provided by Table 1 , followed by the detailed discussion. 
Table 1 Descriptive statistics

\begin{tabular}{|c|c|c|c|c|c|c|c|c|}
\hline Variables & \multicolumn{2}{|l|}{$X_{1}$} & $\mathrm{X}_{2}$ & $\mathrm{X}_{3}$ & $\mathrm{X}_{4}$ & $\mathrm{X}_{5}$ & $\mathrm{X}_{6}$ & $\mathrm{X}_{7}$ \\
\hline Average & \multicolumn{2}{|c|}{$30,968.5$} & 2.9 & 10.5 & 99.2 & 222.3 & 67.9 & 133.8 \\
\hline Minimum & \multicolumn{2}{|c|}{7043.0} & 0.9 & 4.3 & 93.1 & 82.8 & 55.3 & 62.0 \\
\hline Maximum & \multicolumn{2}{|c|}{$107,206.0$} & 5.7 & 25.0 & 108.0 & 669.9 & 79.4 & 214.3 \\
\hline Standard deviation & \multicolumn{2}{|c|}{$20,374.7$} & 0.9 & 5.2 & 3.7 & 130.6 & 6.3 & 31.6 \\
\hline Coefficient of variety (\%) & \multicolumn{2}{|c|}{65.8} & 31.7 & 49.1 & 3.7 & 58.8 & 9.3 & 23.7 \\
\hline Variables & $\mathrm{X}_{8}$ & $\mathrm{X}_{9}$ & $\mathrm{X}_{10}$ & $\mathrm{X}_{11}$ & $\mathrm{X}_{12}$ & $X_{13}$ & $\mathrm{X}_{14}$ & $\mathrm{X}_{15}^{\mathrm{a}}$ \\
\hline Average & 25.6 & 1.0 & 11.6 & 25.7 & 10.0 & 23.2 & 1.7 & 1.8 \\
\hline Minimum & 15.0 & 0.9 & 3.2 & 13.4 & 1.4 & 5.0 & 0.5 & -1.2 \\
\hline Maximum & 49.3 & 1.3 & 31.8 & 44.2 & 31.6 & 48.0 & 3.6 & 8.9 \\
\hline Standard deviation & 8.2 & 0.1 & 7.1 & 8.4 & 7.5 & 12.0 & 0.9 & 2.7 \\
\hline Coefficient of variety (\%) & 32.2 & 9.4 & 61.2 & 32.8 & 74.8 & 51.7 & 55.2 & 149 \\
\hline
\end{tabular}

Source based on http://epp.eurostat.ec.europa.eu/portal/page/portal/eurostat/home/; http://euro-dane.com.pl; Sytuacja społeczno-gospodarcza w Unii Europejskiej w r. (2013), http://www.stat.gov.pl/gus/5840_11534_ PLK_HTML.htm

${ }^{a}$ Except Luxembourg

\subsubsection{Economy}

The highest level of GDP per capita was observed in 2012 in Luxembourg, followed by Sweden, Austria and the Netherlands. On the other end, Bulgaria and Romania had the lowest GDP per capita. In the same measurement, Poland ranked the 25th among the EU 28 countries, surpassed by such countries as the Czech Republic, Slovakia, Estonia, Latvia, Lithuania, and Hungary. The highest rate of unemployment was in Spain (25\%), followed by Greece $(24.3 \%)$ and Croatia and Portugal $(15.9 \%)$. The rate of unemployment in Poland was $10.1 \%$, similar to Estonia, France, Italy, and Hungary. The rate of employment in Poland was lower than the EU average by about $5.0 \%$. The highest employment rate was observed in Sweden $(79.4 \%)$ and the lowest in Greece $(55.3 \%)$. At the same time, Poland had a relatively higher rate of inflation in 2012, only lower than Hungary $(5.7 \%)$ and Estonia (4.2\%).

The highest market openness, measured as the ratio of export-import, was observed in Ireland (1.29), with the lowest in Greece (0.85). The value of this indicator for Poland (1.01) was lower than the average by about $2.7 \%$. The proportion of exports of hi-tech products in overall exports was $5.9 \%$ in Poland, ranked 22nd in the EU. The highest values of this indicator was observed in Malta (31.8\%), followed by Luxembourg $(26.2 \%)$ and Ireland (20.6 \%), and the lowest value in Portugal (3.2\%), Greece $(3.3 \%)$, and Bulgaria (3.8\%).

Not surprisingly, the percentage of expenditures on R\&D in GDP was pretty low in Poland $(0.9 \%)$, ranked 20th of the EU. In comparison, this rate was the highest in Finland $(3.6 \%)$ and lowest in Cyprus $(0.5 \%)$. For the inflow of FDI as percentage of GDP, the highest value was noted in Luxembourg $(486.5 \%), 54$ times higher than that in Hungary $(8.9 \%)$, the second-highest country. Due to the extremely high dispersion of this variable across the countries, the descriptive statistics of $\mathrm{X}_{15}$ presented in Table 1 excluded Luxembourg. For this indicator, Poland ranked 21 st with a value of $0.1 \%$. Further, an increase 
in industrial production, in comparison to 2011, was observed in Hungary, Malta, Latvia, Lithuania, Romania, Poland and Estonia. The industrial output decreased from 2011 to 2012 in all the other countries.

\subsubsection{Environment}

The economy with the lowest level of energy intensity was Ireland, and the highest was Bulgaria. The value of this indicator for Poland was about $34 \%$, higher than the EU average. Polish economy was also characterized by a lower than average (about $6 \%$ ) resource efficiency. The highest value of that indicator (in $\mathrm{kg}$ oil equivalent per $1000 \mathrm{EUR}$ ) was observed in Ireland (82.8), and the lowest in Romania (669.9).

\subsubsection{Society}

In Poland, $26.7 \%$ of the total population were at risk of poverty or social exclusion, slightly higher than the EU average $(25.6 \%)$, while the highest value of that indicator was observed in Bulgaria (49.3\%) and the lowest in the Netherlands (15\%). However, the economic situation of the young population (25-29 years old) in Poland was more promising. The poverty risk of this age group was $21 \%$, lower than the EU average by $18 \%$. The percentage of people attending in lifelong learning programs in Poland was only $4.5 \%$, twice lower than the EU average. Such a rate was highest in Denmark (31.6\%), followed by Sweden $(26.7 \%)$ and Finland $(24.5 \%)$, and lowest in Romania $(1.4 \%)$. In Poland, $32 \%$ of total population aged 16-74 have never used Internet, and this rate is lower than that in Portugal, Croatia, Cyprus, Italy, Bulgaria, Greece, and Romania.

Next, we assessed the level of variation in these variables. As mentioned in Sect. 2.2, the coefficient of variation is expected to exceed $10 \%$. This condition was not satisfied in case of $\mathrm{X}_{4}$ : change in industrial production, $\mathrm{X}_{6}$ : rate of employment, and $\mathrm{X}_{9}$ : export/import rate. Thus, these features were excluded.

Another criterion for variable selection was the level of correlation among variables which is shown by Table 2. Based on the threshold values of \pm 0.7 (Stec et al. 2014), the following variables were further removed: $\mathrm{X}_{8}$ : percentage of people at risk of poverty/ exclusion, $\mathrm{X}_{12}$ : lifelong learning participation by educational attainment, $\mathrm{X}_{13}$ : percentage of population who has never used Internet; and $\mathrm{X}_{15}$ : inflow of FDI (\% GDP).

Thus, the final accepted indicators include: $\mathrm{X}_{1}$, value of GDP per capita (USD); $\mathrm{X}_{2}$, rate of inflation; $\mathrm{X}_{3}$, rate of unemployment; $\mathrm{X}_{5}$, energy intensity of the economy ( $\mathrm{kg}$ of oil equivalent/1000 EUR); $X_{7}$, resource efficiency (GDP/DMC); $X_{10}$, participation of hi-tech exports; $X_{11}$, rate of poverty/exclusion of people aged 25-29; and $X_{14}$, expenditures on $\mathrm{R} \& \mathrm{D}$ in GDP.

The separate analysis of each variable cannot reflect the multi-dimensions and complexity of national socioeconomic development. As discussed earlier (Table 1), some countries may rank pretty high by certain indicators, but not necessarily by others. Therefore, in order to capture the overall level of development, we further apply a multivariate analysis to produce a synthesized indicator. In this step, we divide the features into stimulants and destimulants. The set of stimulants include the following features: 


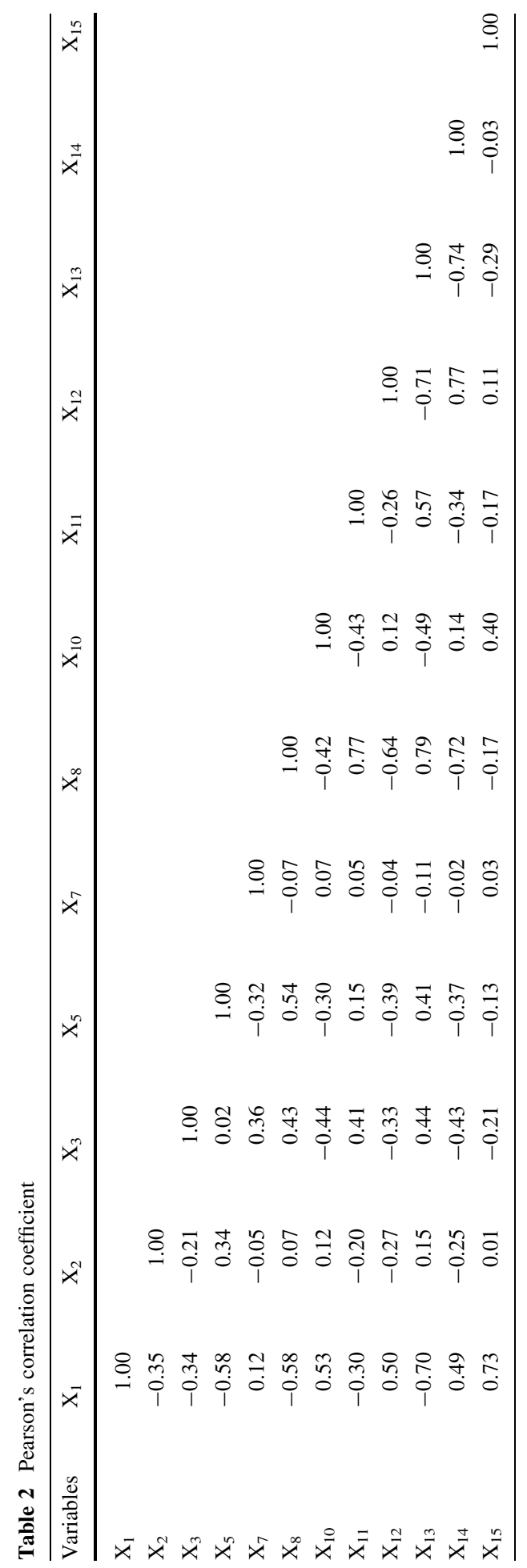




$$
\text { S: }\left\{\mathrm{X}_{1}, \mathrm{X}_{7}, \mathrm{X}_{10}, \mathrm{X}_{14}\right\} \text {, }
$$

while the set of destimulants include the following:

$$
\text { D: }\left\{\mathrm{X}_{2}, \mathrm{X}_{3}, \mathrm{X}_{5}, \mathrm{X}_{11}\right\} \text {. }
$$

Finally, we use Formula (3) to standardize the features' values based on which we use Formulas (4)-(8) to obtain the ranking of the EU counties.

\section{Results and discussion}

\subsection{Ranking of EU countries}

The level of overall socioeconomic development is represented by Table 3. Luxemburg, France and Sweden who belong to the old EU member states (EU 15) top the ranking. Above average are also the other members of the EU 15, except for Italy, Portugal, Spain and Greece who are classified below average. Among those which entered EU in 2004, the level of socioeconomic development is above the average in the following countries (from the top): Slovenia, the Czech Republic, Malta, and Cyprus. In the same 2004 EU country group, the development in Lithuania, Slovakia, Latvia, Poland, Estonia, and Hungary are below the average. Croatia, the newest member state of EU (entered EU in 2013), also ranks lower in the development hierarchy, followed by Romania and Bulgaria which joined EU in 2007.

Differentiation in the countries' development level is confirmed by the coefficient of variation $(27.84 \%)$. Moreover, a weak left-handed asymmetry $(A s=-0.81)$ of indicator's values shows preponderance of countries developed better than the average. Above the average were classified 15 from 28 countries. However, the development level of the

Table 3 Level of socioeconomic development in the EU countries

\begin{tabular}{llllllll}
\hline Rating & EU 28 & $\mathrm{di}$ & $\mathrm{di}^{\prime}$ & Rating & EU 28 & $\mathrm{di}$ & $\mathrm{di}^{\prime}$ \\
\hline 1 & Luxembourg & 0.86 & 100.00 & 15 & Cyprus & 0.63 & 73.27 \\
2 & France & 0.83 & 96.36 & 16 & Italy & 0.62 & 72.07 \\
3 & Sweden & 0.82 & 96.29 & 17 & Portugal & 0.58 & 67.88 \\
4 & Netherlands & 0.82 & 95.49 & 18 & Lithuania & 0.57 & 67.11 \\
5 & Germany & 0.80 & 93.40 & 19 & Slovakia & 0.54 & 63.29 \\
6 & Austria & 0.80 & 93.25 & 20 & Latvia & 0.54 & 62.86 \\
7 & UK & 0.79 & 92.62 & 21 & Poland & 0.53 & 62.33 \\
8 & Ireland & 0.78 & 90.90 & 22 & Spain & 0.51 & 59.08 \\
9 & Belgium & 0.74 & 86.62 & 23 & Estonia & 0.48 & 55.48 \\
10 & Finland & 0.74 & 86.08 & 24 & Hungary & 0.47 & 55.31 \\
11 & Slovenia & 0.74 & 86.04 & 25 & Croatia & 0.46 & 54.24 \\
12 & Czech Republic & 0.70 & 82.23 & 26 & Greece & 0.34 & 39.50 \\
13 & Denmark & 0.70 & 81.72 & 27 & Romania & 0.29 & 34.22 \\
14 & Malta & 0.69 & 80.60 & 28 & Bulgaria & 0.17 & 19.68 \\
\hline
\end{tabular}


first in the ranking, Luxemburg, is more than five times higher than that in the last, Bulgaria. This difference indicates extreme unevenness in socioeconomic development among the EU.

\subsection{Grouping of EU countries}

Based on the synthetic indicator of national socioeconomic development, the EU 28 member states are classified into four groups, as shown in Table 4 and Fig. 1.

The overall classification of socioeconomic development for the EU 28 member states is also mapped in Fig. 1.

The first group of highly developed countries were characterized with high GDP per capita, high standard of living, a relatively low level of unemployment (except for France where the unemployment rate was $10.2 \%$ ). The overall pattern indicates a stable labour market and minor risks of poverty or social exclusion, in particular among the youth. These economies have grown rapidly in the development of new technologies, supported by high expenditures on R\&D. The significantly high proportion of hi-tech products in their exports confirms the innovativeness of these countries.

The second group, countries with the level of development higher than the average but lower than the first group, included Germany, Austria, UK, Ireland, Belgium, Finland, Slovenia, the Czech Republic, Denmark, Malta, and Cyprus. These are countries with welldeveloped economies, stable socioeconomic situations, high living standards, as well as environment-friendly economies characterized by low emissions. Malta and Cyprus ranked particularly high in this group, 14th and 15th, respectively. Malta was characterized by its high level of innovativeness in exports $(31.8 \%)$ and low risk of poverty and exclusion amongst the youth $(15.1 \%)$, as well as low unemployment rate $(6.4 \%)$. Cyprus had a relatively high share of population aged 24-64 participating in lifelong learning programs, as well as its innovativeness in exports $(11.7 \%)$.

Lower than the average level of socioeconomic development (Group III) was noted in Italy, Portugal, Lithuania, Slovakia, Latvia, Poland, Spain, Estonia, Hungary, and Croatia. The GDP per capita was lower than average in all these countries except for Italy. The rate of employment was also lower than the EU 28 average except for Estonia and the rate of unemployment in the third group (with the exception of Estonia and Lithuania) was higher than the EU average. Their living standards were also lower when compared to the first and second groups. The situation of this group was further deteriorated by the poor participation in lifelong education among its population. Moreover, there was a high proportion of people aged 16-74 who had never used the Internet. Further, lower expenditures on

Table 4 Classification of the EU member states by their level of development

\begin{tabular}{lll}
\hline Groups & Ranges & EU 28 countries \\
\hline I & $d_{i}^{\prime}>93.50$ & Luxembourg, France, Sweden, Netherlands \\
II & $73.14<d_{i}^{\prime} \leq 93.50$ & $\begin{array}{c}\text { Germany, Austria, UK, Ireland, Belgium, Finland, Slovenia, } \\
\text { Czech Republic, Denmark, Malta, Cyprus }\end{array}$ \\
III & $52.78<d_{i}^{\prime} \leq 73.14$ & $\begin{array}{c}\text { Italy, Portugal, Lithuania, Slovakia, Latvia, Poland, Spain, } \\
\text { Estonia, Hungary, Croatia }\end{array}$ \\
IV & $d_{i}^{\prime} \leq 52.78$ & Greece, Romania, Bulgaria \\
\hline
\end{tabular}




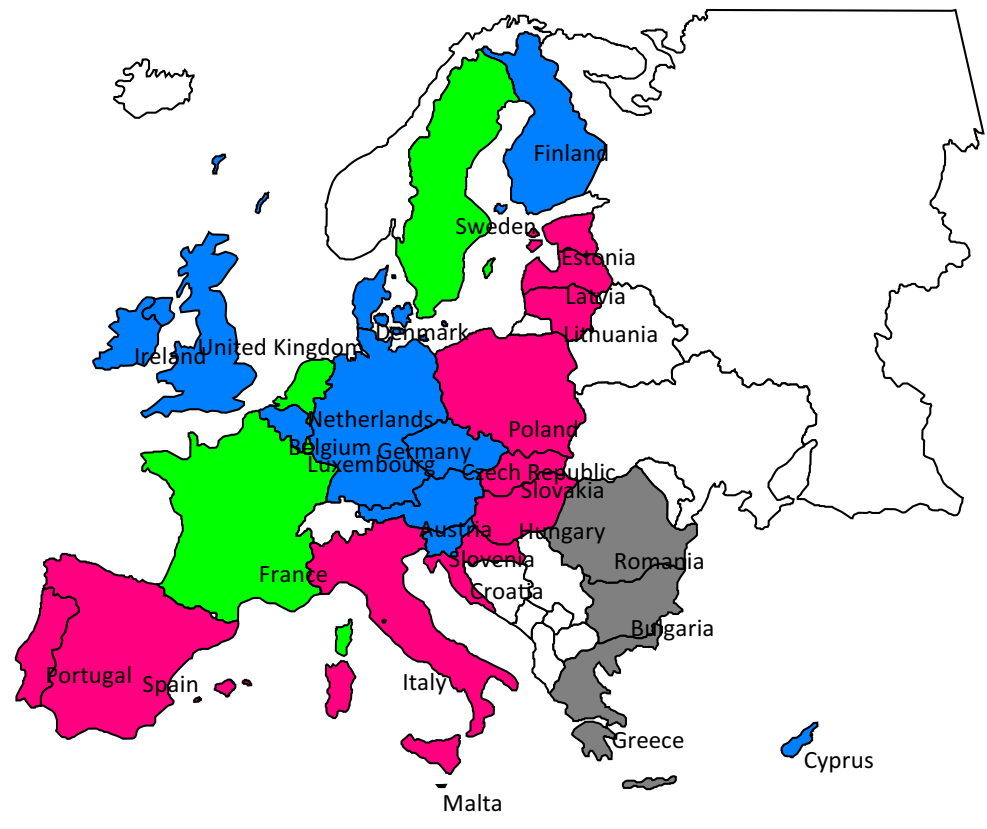

Group I

Group II

Group III

Group IV

Fig. 1 Classification of the EU 28 countries by the level of socioeconomic development

R\&D further took away the opportunities for innovations and development of new technologies there. Poland was rated 21st, ahead of Spain, Estonia, Hungary and Croatia from the same group. The unemployment rate, the growth rate of industrial production, and the exports-imports ratio for Poland were slightly better than the EU average. However, values for all the other indicators pointed to a worse than the average socioeconomic situation of Poland.

Worst of all member states, Greece, Romania and Bulgaria were among the countries with the lowest level of socioeconomic development (Group IV). Greece, which was the most severely affected by the economic crisis of recent years, exhibited one of the highest rate of unemployment amongst the EU countries. The unfavourable situation of the fourth group countries was further reflected by the highest percentage of people aged 25-64 not attending lifelong learning, the highest percentage of people not using Internet, and the significantly high risk of poverty among the young and the total population. The weak socioeconomic situation of Bulgaria and Romania was also reflected by the high energy intensity of the economy, which was over three times higher in Bulgaria and almost twice higher in Romania than the EU average. Moreover, their extremely limited expenditures on R\&D had significantly impeded their economic growth and widened their gap of development with the most developed states, such as Luxemburg, France, Sweden or the Netherlands.

\subsection{Hypothesis verification}

As shown in Table 5, in 2011, the top three countries within EU with the largest number of ISO 14001 certificates were Italy $(17,418)$, Spain $(16,341)$ and UK $(15,231)$. Ranked at 10th, Poland had 1900 certificates, after the Czech Republic (4451) but ahead of Slovakia 


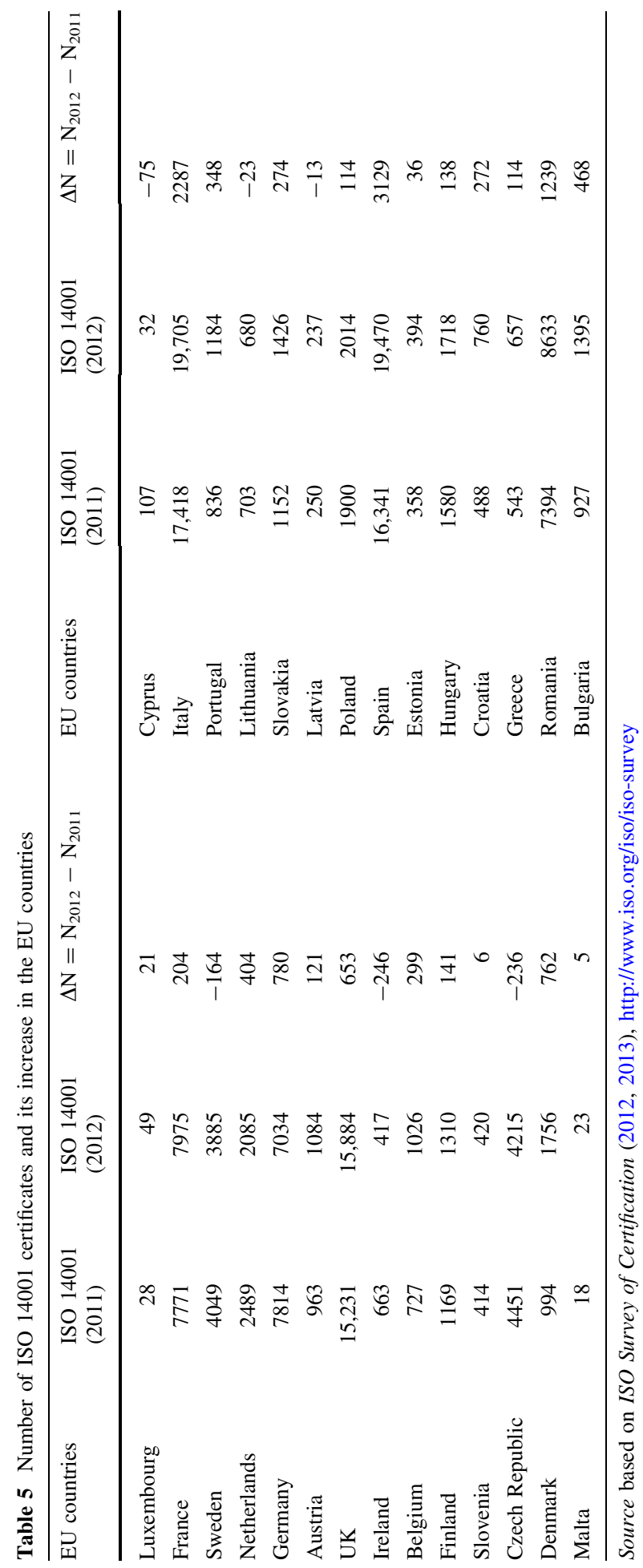


(1152). Measured by national development, both of these two Central-Eastern Europe countries ranked higher than Poland (Table 3).

The top three countries with the largest number of the ISO 14001 certificates in 2012 were still the same: Italy $(19,705)$, Spain $(19,470)$ and UK $(15,884)$. Poland still ranked 10th, with the total number of certificates increased to 2014. The highest increase from 2011 to 2012 in the total number of the ISO 14001 certificates was in Denmark (43.4\%), Croatia (35.8\%), and Bulgaria (33.5\%). The annual increase for Poland was $6 \%$. A decrease in the number of ISO 14001 certificates was noted in Cyprus (70 \%), Ireland $(37.1 \%)$, the Czech Republic (5.3\%), Latvia (5.2\%), Sweden (4.1\%), and Lithuania $(3.3 \%)$.

If considering the population size in each country (Fig. 2), the top five countries in the number of certificates per capita were Malta, Italy, UK, the Czech Republic, and the Netherlands. Poland ranked 23rd, followed by Ireland, Greece, Finland, Latvia, and Cyprus.

The highest relative increase in ISO 14001 was observed in Denmark, Malta, Belgium, Netherlands, and Luxemburg (Fig. 3). The decrease was however observed in six countries: Cyprus, Ireland, the Czech Republic, Sweden, Lithuania, and Latvia. Poland observed an increase in ISO 14001 number per capita, but, the level of growth was one of the lowest, comparable to Finland, France or Slovenia.

Table 6 presents Pearson's correlation results on the relationship between ISO 14001 certification adoption and the EU countries' development. Between the number of ISO 14001 certificates and the synthetic indicator of socioeconomic development we observed a very weak negative correlation (-0.16). A stronger correlation $(-0.29)$, however, was observed between the growth of certificates (from 2011 to 2012) and the level of development. The negative sign of the both coefficients of correlation shows that the adoption of ISO 14001 standard was more likely to be observed in countries with a lower level of socioeconomic development, rather than in more developed countries.

\section{Discussion and conclusion}

The assessment of national socioeconomic development is exceptionally difficult, due to the complexity of the phenomenon and the difficulty in measuring the diagnostic variables. Through the application of a Hellwig's synthetic indicator of development, this study has examined the level of socioeconomic development of the EU member states. Consistent with existing studies in this area (e.g., Kuc 2012; Olczyk 2014; Grzebyk and Stec 2015),

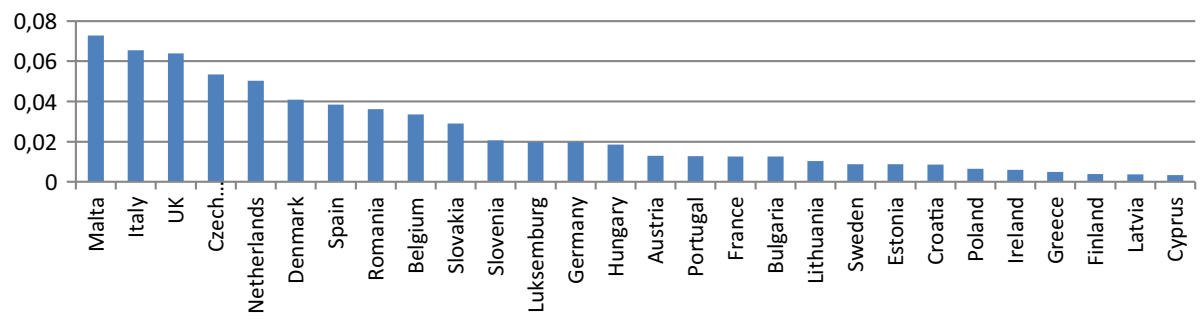

Fig. 2 ISO 14001 certificates per capita in the EU countries (2012) 


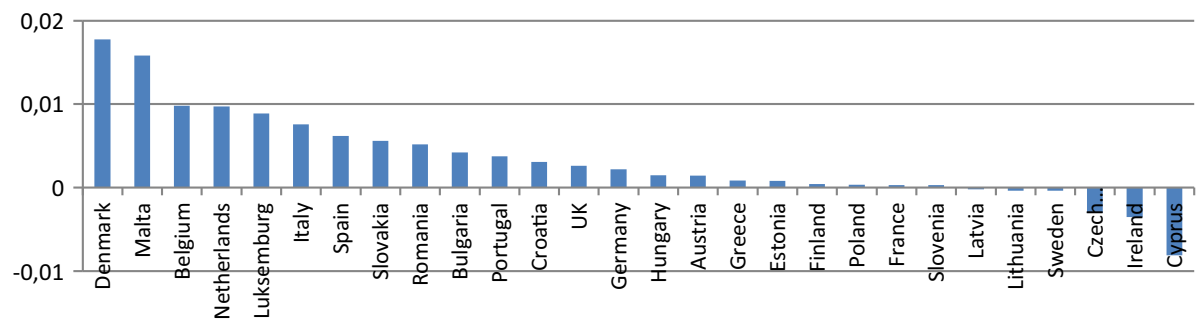

Fig. 3 Change in ISO 14001 certificates number per capita in the EU countries (from 2011 to 2012)

Table 6 Pearson's correlation results

\begin{tabular}{lr}
\hline Pair of variables & $\mathrm{r}$ \\
\hline ISO 14001 certificates per capita and EU national development & -0.1573 \\
Increase of ISO 14001 certificates per capita and EU national development & -0.2913 \\
\hline
\end{tabular}

there is a significant variation in the level of development within the EU member states, as showed by the coefficients of variation $(27.84 \%)$.

The primary goal of this study is to examine the adoption of ISO 14001 certification system in the EU member states. The results show that the level of national socioeconomic development is a factor associated with the diffusion of ISO 14001 environmental management system in the EU countries. The analyses verified our hypothesis that there is a correlation between the level of national socioeconomic development and the adoption of the ISO 14001 certification. Specifically, while there was no relationship between the number of ISO 14001 certificates and the level of socioeconomic development at the national level in 2012, a weak negative correlation was observed between the increase of certification from 2011 to 2012 and the level of national socioeconomic development. The results suggest a higher interest in the ISO 14001 adoption by firms from less developed countries than that by the firms located in the highly developed states. Such a result is consistent with some existing research, e.g., by Chapple et al. (2001) who argue that ISO 14001 certificate adoption tends to be less likely when a firm becomes more powerful in terms of its level of export, market share, and profitability. They are also in line with the research by Heras-Saizarbitoria et al. (2015) which shows that the adoption of environmental management systems among the EU member states differs by environmental impacts of economic activities sectors.

The observed relationship is moreover supported by the theory of performance frontiers (Schmenner and Swink 1998). According to this theory, the best returns from investmentincluding environmental investments-should be expected in the early stage of implementation. After the initial stage, the positive effects of investments demand additional resources (Vastag 2000). It seems that improvements resulting from international standard certification are more substantial in less developed countries with large productivity differences among the companies, most of which function below the technological possibility frontier. In such environments, international management standards can significantly help firms move up the technological ladder, improve their productivity, and enhance their public images (Goedhuys and Sleuwaegen 2013). Therefore, the higher potential benefits 
accrued from the ISO 14001 adoption in less developed countries might explain the higher increase of ISO 14001 certification in these countries.

While the implementation of ISO 14001 environmental management system still remains an important tool for market success, such interests are mainly from less developed countries. Apparently, the high level of national socioeconomic development seems not translating into a higher interest in compliance with ISO 14001 certification. Less interest in ISO 14001 certification in businesses from more developed countries might be however explained by the saturation in the system adoption. And consequently, higher interest in the adoption by firms in developing countries might also be connected with the less mature certification systems. Further research needs to be conducted to compare the level of saturation in ISO 14001 certification between more and less developed countries.

Acknowledgments The work presented in the paper is supported by the Ministry of Science and Higher Education (MNiSW) in Poland.

Open Access This article is distributed under the terms of the Creative Commons Attribution 4.0 International License (http://creativecommons.org/licenses/by/4.0/), which permits unrestricted use, distribution, and reproduction in any medium, provided you give appropriate credit to the original author(s) and the source, provide a link to the Creative Commons license, and indicate if changes were made.

\section{References}

Bansal, P., Bogner, W.C.: Deciding on ISO 14001: economics, institutions, and context. Long Range Plan. 35, 269-290 (2002)

Borys, T.: Sustainable development as an educational challenge. Argum. Oecon. 24(1), 5-19 (2010)

Casadesús, M., Marimon, F., Heras, I.: ISO 14001 diffusion after the success of the ISO 9001 model. J. Clean. Prod. 18, 1741-1754 (2008)

Chapple, W., Cooke, A., Galt, V., Paton, D.: The characteristics and attributes of the UK firms obtaining accreditation to ISO 14001. Bus. Strategy Environ. 10, 238-244 (2001)

Chen, Y.-S., Chang, K.-C.: The nonlinear effect of green innovation on the corporate competitive advantage. Qual. Quant. 47, 271-286 (2013)

Fikru, M.G.: International certification in developing countries: the role of internal and external institutional pressure. J. Environ. Manag. 144, 286-296 (2014)

Franchetti, M.: ISO 14001 and solid waste generation rates in US manufacturing organizations: an analysis of relationship. J. Clean. Prod. 19, 1104-1109 (2011)

Fura, B.: Improving ISO 14001 environmental management systems. Pol. J. Environ. Stud. 22(6), 1711-1721 (2013)

Gavronski, I., Ferrer, G., Paiva, E.L.: ISO 14001 certification in Brazil: motivations and benefits. J. Clean. Prod. 16, 87-94 (2008)

Goedhuys, M., Sleuwaegen, L.: The impact of international standards certification on the performance of firms in less developed countries. World Dev. 47, 87-101 (2013)

Gostowski, Z.: The use of taxonomic measures in target setting based on international comparisons. Qual. Quant. 4(2), 355-363 (1970)

Grzebyk, M., Stec, M.: Sustainable development in EU countries: concept and rating of levels of development. Sustain. Dev. 23, 110-123 (2015)

Guyon, I., Elisseeff, A.: An introduction to variable and feature selection. J. Mach. Learn. Res. 3, 1157-1182 (2003)

Hąbek, P.: Evaluation of sustainability reporting practices in Poland. Qual. Quant. 48, 1739-1752 (2014)

Hąbek, P., Wolniak, R.: Assessing the quality of corporate social responsibility reports: the case of reporting practices in selected European Union member states. Qual. Quant. (2015). doi:10.1007/s11135-0140155-z

He, W., Liu, Ch., Lu, J., Cao, J.: Impacts of ISO 14001 adoption on firm performance: evidence from China. China Econ. Rev. 32, 43-56 (2015)

Hellwig, Z.: Zastosowanie metody taksonomicznej do typologicznego podziału krajów ze względu na poziom rozwoju i strukturę kwalifikowanych kadr. Prz. Stat. 4, 307-327 (1968) 
Heras-Saizarbitoria, I., Arana, G., Boiral, O.: Exploring the dissemination of environmental certifications in high and low polluting industries. J. Clean. Prod. 89, 50-58 (2015)

http://epp.eurostat.ec.europa.eu/portal/page/portal/eurostat/home/ (2014). Accessed 15 Dec 2014

http://www.euro-dane.com.pl (2014). Accessed 15 Dec 2014

http://www.stat.gov.pl (2014). Accessed 15 Dec 2014

Išljamović, S., Jeremić, V., Petrović, N., Radojičić, Z.: Colouring the socio-economic development into green: I. distance framework for countries' welfare evaluation. Qual. Quant. 49(2), 617-629 (2015)

Kuc, M.: The implementation of synthetic variable for constructing the standard of living measure in European Union countries. Oecon. Copernic. 3, 5-19 (2012)

Lagodimos, A.G., Chountalas, P.T., Chatzi, K.: The state of ISO 14001 certification in Greece. J. Clean. Prod. 15, 1743-1754 (2007)

Lesot, M.-J.: Outlier preserving clustering for structured data through kernels. In: Spiliopoulou, M., Kruse, R., Borgelt, C., Gaul, W. (eds.) From Data and Information Analysis to Knowledge Engineering, pp. 462-469. Springer, Berlin (2006)

Marimon, F., Llach, J., Bernardo, M.: Comparative analysis of diffusion of the ISO 14001 standard by sector of activity. J. Clean. Prod. 19, 1734-1744 (2011)

McGuire, W.: The effect of ISO 14001 on environmental regulatory compliance in China. Ecol. Econ. 105, 254-264 (2014)

Neumayer, E., Perkins, R.: What explains the uneven take-up of ISO 14001 at the global level? A panel-data analysis. Environ. Plan. A 36, 823-839 (2004)

Nishitani, K.: Demand for ISO 14001 adoption in the global supply chain: an empirical analysis focusing on environmentally conscious markets. Resour. Energy Econ. 32(3), 395-407 (2010)

Olczyk, M.: Structural heterogeneity between EU 15 and 12 new EU members-the obstacle to Lisbon strategy implementation? Q. J. Econ. Econ. Policy 9(4), 21-43 (2014)

Ostasiewicz, W.: Statystyczne metody analizy danych. AE, Wrocław (1998)

Perło, D.: Environmental quality as a decisive variable in shaping regional development policy. Stud. Log. Gramm. Rhetor. 37(50), 159-178 (2014). doi:10.2478/slgr-2014-0023

Pociecha, J., Zając, K.: Cluster analysis methods and regression modelling. Control Cybern. 18(1), 69-80 (1989)

Qi, G.Y., Zeng, S.X., Yin, H.T., Wu, J.F., Dai, Z.H.: Diffusion of ISO 14001 environmental management systems in China: rethinking on stakeholders' roles. J. Clean. Prod. 19, 1250-1256 (2011)

Sarama, M.: Comparative analysis of the information society development level in the poviats of the Podkarpackie Voivodship. Quant. Methods Econ. 32, 351-366 (2013)

Schmenner, R.W., Swink, M.L.: On the theory in operations management. J. Oper. Manag. 17, 97-113 (1998)

Stec, M., Filip, P., Grzebyk, M., Pierscieniak, A.: Socio-economic development in the EU member statesconcept and classification. Eng. Econ. 25(5), 504-515 (2014)

Sytuacja społeczno-gospodarcza w Unii Europejskiej w 2013 r. http://www.stat.gov.pl/gus/5840_11534_ PLK_HTML.htm (2014). Accessed 15 Dec 2014

Takahashi, T., Nakamura, M.: The impact of operational characteristics on firms' EMS decisions: strategic adoption of ISO 14001 certification. Corp. Soc. Responsib. Environ. Manag. 17, 215-229 (2010)

Testa, F., Rizzi, F., Daddi, T., Gusmerotti, N.M., Frey, M., Iraldo, F.: EMAS and ISO 14001: the differences in effectively improving environmental performance. J. Clean. Prod. 68, 165-173 (2014)

The ISO survey of certification 2012. http://www.iso.org/iso/iso-survey. Accessed 15 Dec 2014

The ISO survey of certification 2013. http://www.iso.org/iso/iso-survey. Accessed 10 April 2015

To, W.M., Lee, P.K.C.: Diffusion of ISO 14001 environmental management system: global, regional and country-level analyses. J. Clean. Prod. 66, 489-498 (2014)

Turk, A.M.: The benefits associated with ISO 14001 certification for construction firms: Turkish case. J. Clean. Prod. 17, 559-569 (2009)

Vastag, G.: Theory of performance frontiers. J. Oper. Manag. 18, 353-360 (2000)

Zobel, T.: ISO 14001 certification in manufacturing firms: a tool for those in need or an indication of greenness? J. Clean. Prod. 43, 37-44 (2013) 